\title{
Primary Health Care in Brasil in the times of COVID-19: changes, challenges and perspectives
}

\author{
(D) Vanessa Tavares de Gois-Santos ${ }^{1}$ \\ (iD) Victor Santana Santos ${ }^{2}$ \\ (D) Carlos Dornels Freire de Souza ${ }^{3}$ \\ (iD) Carolina Santos Souza Tavares ${ }^{1}$ \\ (iD) Ricardo Queiroz Gurge/ ${ }^{1}$ \\ (iD) Paulo Ricardo Martins-Filho,4
}
1. Programa de Pós-Graduação em Ciências da Saúde. Universidade Federal de Sergipe, Aracaju, SE, Brasil. 2. Núcleo de Epidemiologia e Saúde Pública. Universidade Federal de Alagoas, Arapiraca, AL, Brasil. 3. Departamento de Medicina. Universidade Federal de Alagoas, Arapiraca, AL,Brasil. 4. Laboratório de Patologia Investigativa. Universidade Federal de Sergipe, Aracaju, SE, Brasil.

http://dx.doi.org/10.1590/1806-9282.66.7.876

\section{SUMMARY}

The pandemic of Coronavirus Disease 2019 (COVID-19) has put pressure on countries' health systems. Although attention is mostly directed at the hospital sector, since many critically ill people will need intensive care, Primary Health Care (PHC) has also been disrupted. In Brasil, a universal and free health system has existed since the 1988 Constitution, which re-organized the PHC to attend the population. However, like other countries, the Brazilian health system is being overloaded with the increase in the large number of COVID-19 cases. It is worth reflecting on the changes and challenges in PHC during the COVID-19 pandemic in Brasil.

KEYWORDS: Primary Health Care. Brasil. Coronavirus Infections.

Dear Editor,

We are going through unprecedented times. The emergence of Severe Acute Respiratory Syndrome Coronavirus 2 (SARS-CoV-2) and its spread worldwide has exposed gaps in the health systems of several countries. As the focus became hospital care, since $15 \%$ of critically ill patients will need intensive care, there has been a disruption in other sectors of the health systems ${ }^{1}$. Such an impact has also been observed in the Primary Health Care (PHC) systems. It is worth reflecting on the changes suffered by PHC during the 2019 Coronavirus Disease (COVID-19) pandemic in Brasil and how PHC itself can function as an important ally in combating the COVID-19 and contributing to reducing the burden on the hospital network.
In Brasil, the 1988 Constitution represented an instrument of change and a social movement that established health as a social right for the Brazilian population. The constitution mandated the state's responsibility to deliver health care to all, paving the way to the Unified Health System (Sistema Único de Saúde [SUS], in Portuguese), which is based on the pillars of university, integrality, and equity. Since then, the health systems have been systematized into levels of care, as primary, secondary and tertiary, with special importance for Primary Health Care (PHC). PHC is the essence of SUS itself, with a focus on programmatic actions, whose municipal managers along with the population (social control) become decision-makers 
for health actions implementation ${ }^{2}$. PHC started in Brasil in 1994, through the Family Health Program, and in 1998 became the Family Health Strategy (FHS). In 1998, there were 2,054 family health teams, and in 2018 the number of teams reached 41,619 covering approximately $75 \%$ of the country population (approximately 143 million individuals) $)^{3}$.

Although each municipal manager determines which priority health actions are to be tackled, there is a national agenda with well-established guidelines that must be followed. In this context, the control of hypertension and diabetes, reproductive familiar planning, prenatal care, childcare, control of communicable diseases (most notably dengue, zika, leprosy, tuberculosis, and sexually transmitted infections) and others are among the PHC's priority actions. In addition, the PHC works as a capillary network to guide the flow of individuals who need procedures in specialized clinics and/or hospitals. However, the current crisis triggered by COVID-19 imposes changes in the PHC schedule and in its work process.

Among the main topics discussed and subsequently modified are the implementation of a care plan for suspected cases of COVID-19 and the reorganization of priority demand in primary health units. In the contingency plan for coping with the COVID-19, some primary care units located at strategic points in the territory were designated as reference units for the treatment of respiratory syndromes (flu-like syndromes), as the cases of COVID-19 show unspecified symptoms.

Health professionals were trained for the early recognition of signs and symptoms of severity initial care, transfer of cases to medium and high complexity units, as well as to proceed with the collection of material from the respiratory tract to be sent to the Central Laboratory of Public Health, where RT-PCR assays are carried out for the diagnosis of COVID-19. The respiratory samples are tested for a respiratory viral panel to identify other viruses that are concomitant, seasonal, and usually prevalent. For this purpose, the population has been extensively informed about where the reference units are located and on what occasions they should seek assistance there. Even with the widespread broadcasting of announcements, many people who are unable to access quality information still do not know how to seek help, which reveals flaws in the system.

In addition to the reference units and considering the importance of PHC in the community transmission phase, the Ministry of Health launched the Coronavirus Clinical Management Protocol for Primary Health Care with the intention of standardizing the work process at that attention level, ensuring security and resolution ${ }^{4}$.

Because the SARS-CoV-2 is a highly infectious pathogen transmitted mainly by droplets and airborne, protocols have been instituted in primary health care, especially to people reporting respiratory symptoms ${ }^{5}$. There has been extensive reinforcement for the correct use of facial masks and frequent handwashing by health professionals. Patients who seek care are also instructed not to be in crowded spaces and wash hands frequently, and face masks are mandatory for those with flu-like symptoms (currently to all). Suspected cases with mild symptoms are prescribed anti-symptomatic medication and are instructed to maintain social isolation at home for a period of 14 days. They are also instructed to seek a hospital if they experience worsening of symptoms, including shortness of breath $^{6}$. The COVID-19 pandemic also caused alterations in the flow of care in primary health care units. With the increase in suspected cases of COVID-19 and to avoid further pressure on PHC, primary health units reorganized their schedules to prioritize care for respiratory problems and urgent cases. Antenatal care schedules have been maintained, but many routine programs designed to control certain conditions, which are also important, have received less attention. For example, in many situations, actions to control hypertension and diabetes have been suspended, with only the renewal of prescriptions or emergency care being preserved. Community preventive actions, which could cause agglomerations, were temporarily canceled. It is worth mentioning that these agreements may vary from municipality to municipality, according to the local manager's understanding.

Regarding dental care, it was defined by the Federal Council of Dentistry that urgent and emergency procedures should be prioritized over elective procedures that could await care in a period of less transmissibility and risk for COVID-19 $9^{7}$. Professionals started to prioritize cases in which users were experiencing pain or changes in oral tissues, taking the user to greater risk (such as abscesses and dental infections), strictly following recommendations for professional dental care safety $^{8}$.

In times of the COVID-19 pandemic, the duties for community health workers have also changed. Home visits were reduced, with priority given only 
to patients with difficult mobility, serious health problems, and those who need a medical or nursing visit. Community health agents also started to deliver medicines for continuous use to people routinely assisted by a specific family health team. During the work of these workers, guidelines on social distancing and frequent hand hygiene have been reinforced as they are currently the most appropriate form of prevention'.

To minimize the impact of the COVID-19 pandemic on health care, especially for people with chronic diseases and/or using routine medication, the Brazilian Ministry of Health (MoH), in exceptional and temporary nature, published an ordinance authorizing consultations via Telemedicine - as it is not yet regulated in the country. Telemedicine has focused on pre-clinical care, assistance support, medical consultation, treatment monitoring, and diagnosis, through information and communication technology. It can be used for SUS, as well as in supplementary and private health ${ }^{10}$. However, the limited access to technological resources by the poorest population and the lack of these resources in health units represent obstacles to the implementation of this measure for the public services.

Additionally, the Brazilian $\mathrm{MoH}$ has made digital channels and services available, including a telephone exchange and an app for people to seek health care information not only related to COVID-19. According to data from the $\mathrm{MoH}$, by the first week of April 2020, more than 1 million people sought SUS call centers to receive guidance on signs and symptoms of the COVID-19. This initiative seeks to reduce the burden on the health system and provide information at a distance, reducing queues and patient crowding ${ }^{11}$.

As the cases of COVID-19 started to appear just at the beginning of the seasonal period of flu in Brasil, the Brazilian $\mathrm{MoH}$ decided to anticipate the mass influenza vaccination for the older population and health professionals in order to avoid overlapping and/ or coinfection cases and more pressure on health systems. To avoid agglomeration, influenza vaccination was preferably organized in public, open places, which avoided crowding and queuing with people nearby (squares, sports courts). Some municipalities in the country used the drive-thru system for the vaccination campaign and thereby reduced the possibility of crowding among people eligible for vaccination since they are also the group most at risk for adverse outcomes from COVID-19.

In view of the current epidemiological scenario, the moment seems to be one of uncertainty. The number of cases in Brasil is expected to increase in the first or second half of May. Despite PHC reorganization actions to face the COVID-19 in Brasil, the PHC in Brasil has suffered from reduced financial resources in recent years, which has hampered the work of family health teams.

Thus, it is necessary that in the period of confrontation of COVID-19 (and even afterward), PHC receives a greater contribution of investments, ranging from financial incentives for the acquisition of equipment, structuring of health units, purchase of supplies, including the training of health professionals, and psychological support to them. In addition, the number of family health teams needs to be increased to expand the care to the population. In addition, since this article reflects on the general actions implemented by PHC in Brasil, on-site studies are necessary to verify the specificities and variations that each municipality (or district) has carried out during the COVID19 pandemic.

\section{Author's Contribution}

Gois-Santos, V.T.; Santos, V.S.; Souza, C.D.F and Tavares, C.S.S. worked on the conceptualization, discussion of the theme and writing; Gurgel, R.Q and Martins-Filho, P.R. revised and edited the text.

\section{Conflict of interest}

The authors have no conflict of interest to declare.

\section{Financial support}

This study did not receive any financial support.

\section{REFERENCES}

1. Phua J, Weng L, Ling L, Egi M, Lim C-M, Divatia JV, et al; Asian Critical Care Clinical Trials Group. Intensive care management of coronavirus disease 2019 (COVID-19): challenges and recommendations. Lancet Respir Med. 2020;8(5):506-17.
2. BRASIL. Ministério da Saúde, Conselho Nacional de Saúde. Lei n. 8.080, de 19 de setembro de 1990. Dispõe sobre as condições para a promoção, proteção e recuperação da Saúde, a organização e o funcionamento dos serviços correspondentes e dá outras providências. Diário Oficial da União; 19 de setembro de 1990. Brasília: Ministério da Saúde; 1990. [cited 
2020 May 13]. Available from: http://conselho.saude.gov.br/legislacao/ lei8080_190990.htm

3. Pinto LF, Giovanella L. The Family Health Strategy: expanding access and reducing hospitalizations due to Ambulatory Care Sensitive Conditions (ACSC). Cien Saude Colet. 2018;23(6):1903-14.

4. BRASIL. Ministério da Saúde, Secretaria de Atenção Primária à Saúde. Protocolo de manejo clínico do Coronavírus (Covid-19) na atenção primária à saúde. Brasília: Ministério da Saúde; 2020. [cited 2020 May 13]. Availabe from: http://189.28.128.100/dab/docs/portaldab/documentos/20200504 ProtocoloManejo_ver09.pdf

5. World Health Organization. Infection prevention and control during health care when novel coronavirus ( $\mathrm{nCoV}$ ) infection is suspected. Geneva: World Health Organization; 2020. [cited 2020 May 13]. Available from: https:// www.who.int/publications-detail/infection-prevention-and-controlduring-health-care-when-novel-coronavirus-(ncov)-infection-is-suspected-20200125

6. World Health Organization. Considerations for quarantine of individuals in the context of containment for coronavirus disease (COVID-19). World Health Organization. 2020;3-5. [cited 2020 May 13]. Available from: https://www.who.int/publications-detail/considerations-for-quarantine-of-individuals-in-the-context-of-containment-for-coronavirus-disease-(covid-19)

7. BRASIL. Minsitério da Saúde. Coordenação Geral de Saúde Bucal. Nota Técnica no 9/2020-CGSB/DESF/SAPS/MS. COVID-19 e atendimento odontológico no SUS. Brasilia: Minsitério da Saúde; 2020.

8. Martins-Filho PR, Gois-Santos VT, Tavares CSS, Melo EGM, Nascimento-Júnior EM, Santos VS. Recommendations for a safety dental care management during SARS-CoV-2 pandemic. Rev Panam Salud Publica. 2020;44:e51.

9. BRASIL. Ministério da Saúde. Universidade Aberta do SUS - UFMA. Orientações referentes às medidas de prevenção para a comunidade. In: Universidade Aberta do SUS - UFMA. Curso Orientações gerais ao paciente com COVID-19 na Atenção Primária à Saúde. [cited 2020 May 13]. Available from: https://www.unasus.gov.br/cursos/curso/46168

10. BRASIL. Ministério da Saúde. Portaria GM/MS No 467, de 20 de março de 2020. Dispõe, em caráter excepcional e temporário, sobre as ações de Telemedicina, com o objetivo de regulamentar e operacionalizar as medidas de enfrentamento da emergência de saúde pública de importância internacional previstas no art. 3으 da Lei no 13.979, de 6 de fevereiro de 2020, decorrente da epidemia de COVID-19. [cited 2020 May 13]. Available from: http:// www.planalto.gov.br/ccivil_03/Portaria/PRT/Portaria\%20n\%C2\%BA\%20 467-20-ms.htm

11. BRASIL. Ministério da Saúde. Agência Saúde. Ministério da Saúde já atendeu 471,6 mil pessoas à distância: mais de 1 milhão de pessoas procuraram os serviços de teleatendimento do SUS para receber orientações sobre sinais e sintomas do coronavírus. [cited 2020 May 13]. Available from: https:// www.saude.gov.br/noticias/agencia-saude/46675-ministerio-da-saude-jaatendeu-471-6-mil-pessoas-a-distancia 